\title{
ANTHROPOMETRIC PARAMETERS AND BIOCHEMICAL MARKERS OF MILITARY PERSONNEL UNDER THE INFLUENCE OF HIGH PHYSICAL AND PSYCHOLOGICAL LOADS
}

\author{
Liāna Pḷaviṇa ${ }^{1, \#}$, Vitolds Mackēvičs ${ }^{2}$, Silva Smagare ${ }^{1}$, Andris Čakstincš ${ }^{1}$, \\ and Jekaterina Stankēviča ${ }^{1}$

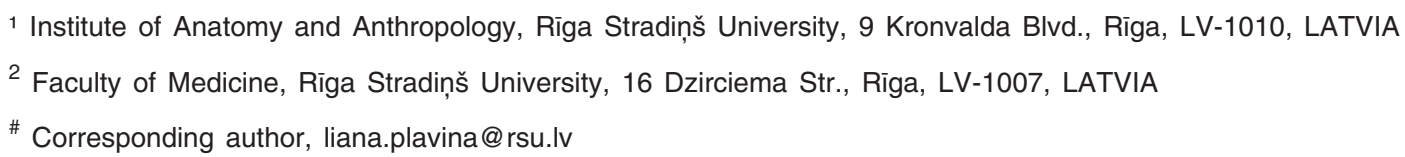

Communicated by Māra Pilmane

\begin{abstract}
Physical fitness, health, and physical endurance are important attributes of persons in military. The purpose of the present study was to assess the changes of anthropometric parameters and of biochemical markers in blood serum for participants of a one-week combat training course (CTC) during which participants had high physical and psychological loads in combination with dietary limitation and sleep deprivation. High physical and psychological loads cause changes in the level of biochemical markers that are indicative of musculoskeletal system dysfunction. The study group included participants $(n=59)$ of both genders aged 23 to 30 years. Anthropometric parameters (body mass, height, body mass index) were determined. Blood plasma analyses were done before and directly after CTC. Biomarkers like lactate dehydrogenase (LDH), creatine phosphokinase (CPK), alanine amino transferase (ALT) and aspartate amino transferase (AST) were measured. Data were analysed by using SPSS 20. We determined levels of anthropometric parameters before, during and after a combat training course. The body mass decreased during the one-week training course, until the sixth day of combat training course, when the peak of physical and emotional stress was reached. The level of biomarkers lactate dehydrogenase and creatine phosphokinase sharply increased after the combat training course. A high physical load caused changes in biochemical markers, indicating musculoskeletal dysfunction in healthy young persons. The study underlines the importance of checking the health status of military personnel before and after exercises with high physical and psychological loads in order to prevent major health disorders in the combat environment.
\end{abstract}

Key words: body composition, biochemical markers, military personnel, physical load, anthropometric parameters.

\section{INTRODUCTION}

Military personnel are at high risk for health disorders, musculoskeletal pathologies and psychological overload. A large numbers of studies have attempted to identify early signs of clinical manifestation of disorders and dysfunctions of the musculoskeletal system, which contribute to injury risk among military personnel (Nozaki et al., 2009; Wallimann et al., 2011; Jones et al., 2017; Havenetidis et al., 2017; Sanderson et al., 2018; Barringer et al., 2018). Numerous risk factors such as age, gender, anthropometric parameters and physical fitness level may account for muscu- loskeletal injury (Karlsson et al., 1972; Halson, 2014; Clark et al., 2017; McCarthy et al., 2017). The injury risk increases with age. Persons aged 25 and older are at a higher risk of developing musculoskeletal disorders (Backous et al., 1988, Taanila et al., 2015). The injury risk was found to differ based on gender; females had a greater risk of musculoskeletal dysfunctions and injuries than males (Beynnon et al., 2014). Nutrition has an important impact on soft tissue injury risk and recovery (Baar, 2015; Jones, 2016; Tassone et al., 2017). Enduring a physical load as a part of military training induces energy expenditure, nutrition status changes, body composition changes and biochemical 
changes (Liberman et al., 2008; Yael et al., 2008; Fallowfield et al., 2014; Naghii et al., 2006; Sammito et al., 2016). Military service quality is related to military personnel physical and psychosocial fitness, which is determined both by personal and occupational risk factors at the service place. Intense and frequent combat training over an extended period with insufficient rest/recovery time may result in exercise-induced tissue trauma resulting in systemic inflammatory response and, possibly, health disorders. Physical fitness is an important risk factor for musculoskeletal disorders, and muscle fatigue potentially predisposes individuals with lower fitness to musculoskeletal disorders (Murphy et al., 2003). Body weight control and assessment of anthropometric characteristics are important to evaluate motor activity and manage exercise strategy (Naghii, 2016; Aandstad et al., 2014; da Rosa et al., 2018). Sharp changes in body mass, body mass index and body fat percentage, as found in some studies, may also influence the rate of musculoskeletal disorders and might be a risk factor for musculoskeletal disorders (Taanila et al., 2010, 2015; Parkkari et al., 2011; Mitchell et al., 2017). A high physical load and an intense field exercises is a compulsory part of military training.

\section{MATERIAL AND METHODS}

We examined cadets at the National Defence Academy of Latvia who participated in a one-week combat training course (CTC). All subjects gave their informed consent to the protocol, which was approved by the local Medical Ethics Committee of the Rīga Stradiňš University for Biomedical Research. Psychological tests for participants of the combat training course were conducted by military psychologists and not included in our report. A CTC is designed to assess physical, cognitive, social and individual attributes of personnel in a specific military environment. A CTC is psycho-emotionally and physically stressful with sleep deprivation and feeding limitation. There were no restrictions in water consumption for combat training course participants. The examined group included cadets $(n=59)$ of both genders ( 12 female and 47 male), aged 23-30 years, who had spent 6 to 48 months in the Armed Forces. The cadets with full military equipment $(22.5 \mathrm{~kg})$ performed tactical exercises that include loaded road marches with obstacle course elements. A standardised examination programme for participants was implemented during the period MayJune, 2017.

The cadets passed through various check-up stages, including general health capacity evaluation. Posture analysis (balance testing and assessment of postural sway) was performed by specialists of the military medical centre to assess baseline functional status of the musculoskeletal system. The current height was measured by anthropometry with an accuracy of $0.001 \mathrm{~m}$. The current body mass was measured by scale with an accuracy of $0.01 \mathrm{~kg}$. The body mass of cadets was determined before the combat training, during the one-week combat training course in the evening of each day before the meal, and after the combat training course. The body mass index (BMI) was calculated as the quotient of body mass $(\mathrm{kg})$ and the square of height $\left(\mathrm{m}^{2}\right)$.

Blood plasma analyses were done before and directly after the combat training course. Analyses were conducted by the E. Gulbis Laboratory, which is an accredited laboratory for laboratory testing that performs high-quality laboratory testing corresponding to the international standard LVS EN ISO/IEC 17025.

Biomarkers like lactate dehydrogenase (LDH), creatine phosphokinase (CPK), alanine amino transferase (ALT) and aspartate amino transferase (AST) as well as glucose (GLU), sodium concentration (Na), potassium level (K), and magnesium level $(\mathrm{Mg})$ were measured.

The obtained data were analysed by means of SPSS 20 version. Anthropometric results are presented as mean \pm SEM (standard error of mean) and the level of significance was defined as $p<0.05$, biochemical markers levels are presented as mean \pm SES (Standard Error of Skewness) and the level of significance was defined as $p<0.001$.

\section{RESULTS}

The standardised environment during the combat training course, which included a combination of various military risk factors (physical exercise, psychological load, dietary limitation, sleep deprivation) provided a unique opportunity to assess individual health characteristics and examine musculoskeletal dysfunction by regular anthropometric checkups and measurement of biochemical markers before and after training. Complete data were obtained from 58 cadets-participants (12 females and 46 males). Participants of the CTC were divided into two groups according to gender: male group (Table 1) and female group (Table 2). The mean body mass before the combat training course in the male group was $85.53 \pm 1.70 \mathrm{~kg}$, ranging from $65 \mathrm{~kg}$ to 117 $\mathrm{kg}$. A total of $63.8 \%$ of participants had a body mass from $80 \mathrm{~kg}$ to $100 \mathrm{~kg}$. The body mass was between $65 \mathrm{~kg}$ and 80 $\mathrm{kg}$ for $27.6 \%$ of male participants. The body mass value exceeded $100 \mathrm{~kg}$ in $8.5 \%$ of participants. The mean body mass index (BMI) in the male group was $26.50 \pm 0.37$ (range 21.88 to 33.24$)$. In $42.5 \%$ of male participants BMI was in the reference range according to World Health Organisation recommendations. Up to a $10 \%$ increase of BMI (25.027.9) above the reference range was observed in $48.9 \%$ of participants in the male group. The overweight category, indicated by a BMI $20 \%$ over the standard level (28.0-30.0) occurred in $8.5 \%$ of participants in the male group. BMI exceeded by $30 \%$ over the standard level (over 30.0) was found for one participant. The mean height in the male group was $182.9 \pm 0.9 \mathrm{~cm}$, ranging from $170 \mathrm{~cm}$ to $199 \mathrm{~cm}$. In $23.4 \%$ of male participants, height exceeded $190 \mathrm{~cm}$, and in $76.6 \%$ of male participants, height was below $190 \mathrm{~cm}$. The mean body mass of female participants was $68.67 \pm$ $2.12 \mathrm{~kg}$, ranging from $55 \mathrm{~kg}$ to $79 \mathrm{~kg}$. The mean BMI in the female group was $25.44 \pm 0.74$, varying from 21.34 to 30.10. In $75 \%$ of female participants BMI was in the normal 
Table 1

CHANGES OF BODY MASS INDEX VALUES IN MALE GROUP DURING COMBAT TRAINING COURSE (CTC)

\begin{tabular}{l|c|c|c|c|c|c}
\hline & $\begin{array}{c}\text { CTC } \\
\text { start }\end{array}$ & $2^{\text {nd }}$ day & $3^{\text {rd }}$ day & $4^{\text {th }}$ day & $5^{\text {th }}$ day & $\begin{array}{c}\text { CTC } \\
\text { finish }\end{array}$ \\
\hline Mean & 26.5017 & 26.1806 & 25.9028 & 25.3704 & 25.0791 & 25.5093 \\
SEM & 0.37937 & 0.35978 & 0.36288 & 0.35966 & 0.36669 & 0.35659 \\
SD & 2.60082 & 2.46655 & 2.46119 & 2.43933 & 2.48704 & 2.41854 \\
Minimum & 21.68 & 21.39 & 21.39 & 21.10 & 20.81 & 20.81 \\
Maximum & 33.24 & 32.41 & 32.13 & 31.85 & 31.85 & 31.85
\end{tabular}

SEM, standard error of mean; SD, standard deviation

Table 2

CHANGES OF BODY MASS INDEX VALUES IN FEMALE GROUP DURING COMBAT TRAINING COURSE (CTC)

\begin{tabular}{l|cc|c|c|c|c}
\hline & $\begin{array}{c}\text { CTC } \\
\text { start }\end{array}$ & $2^{\text {nd }}$ day & $3^{\text {rd }}$ day & $4^{\text {th }}$ day & $5^{\text {th }}$ day & $\begin{array}{c}\text { CTC } \\
\text { finish }\end{array}$ \\
\hline Mean & 25.4433 & 25.1967 & 24.6758 & 24.2417 & 23.9208 & 24.3858 \\
SEM & 0.74969 & 0.69714 & 0.68582 & 0.70287 & 0.68683 & 0.68315 \\
SD & 2.59700 & 2.41497 & 2.37574 & 2.43480 & 2.37924 & 2.36651 \\
Minimum & 21.34 & 22.02 & 21.38 & 20.75 & 20.75 & 21.34 \\
Maximum & 30.10 & 29.34 & 28.56 & 28.20 & 27.61 & 28.20
\end{tabular}

range, while in the others BMI was $10 \%$ overweight (BMI 25.0-27.9). The mean height in the female group was lower (mean $170.0 \pm 1.4 \mathrm{~cm}$, range $162 \mathrm{~cm}$ to $178 \mathrm{~cm}$ ) than for males. During the combat training course (CTC) all participants had the same physical load and psychological stress level with sleep deprivation and food limitation.

A decrease of body mass was found during the CTC. During the first day of the course $70.6 \%$ of cadets lost $1-2 \mathrm{~kg}$ of body weight, and for $8.5 \%$ of individuals the decrease of body mas reached $3-4 \mathrm{~kg}$, but for $21.8 \%$ of cadets there was no changes of body mass. We found that the body mass decreased daily and maximal loss occurred on the fifth day of combat training when the peak of physical and emotional stress was reached. Body mass loss between 3-4 kg occurred in $50.0 \%$ of participants, and loss of 5-6 kg in $24.1 \%$ of participants. In $25.8 \%$ of cadets mass loss was between $1-2 \mathrm{~kg}$. There was a decrease of the mean BMI for both genders. The rate of BMI decrease was greater for the female group (see Tables 1 and 2).

Biochemical markers were measured before and after the combat training course. Creatine phosphokinase (CPK, reference range for males 52-336 U/L, for females 38-176 $\mathrm{U} / \mathrm{L}$ ) is a specific enzyme found primarily in the heart, skeletal muscle and brain tissue. It was chosen as a marker of possible cardiovascular and musculoskeletal risk. CPK levels were determined before and after the combat training course (CTC). Before the CTC, the cadets had underwent a pre-course training programme that included various physical activities. The mean creatine phosphokinase value with Standard Error of Skewness (SES) before combat training course was $235.97 \mathrm{U} / \mathrm{L} \pm 0.311$ (SES). It was a very variable biomarker and ranged from 57 to $824 \mathrm{U} / \mathrm{L}$ in the participant group. The level of biochemical marker creatine phosphokinase (CPK) exceeded the reference range in $42.4 \%$ of participants before the combat training course.

During the combat training course, cadets had vigorous physical activities that resulted in abrupt increase of creatine phosphokinase (CPK) levels that exceeded the reference range in $98.2 \%$ of participants after the combat training course. The McNemar statistical test revealed significantly raised $\mathrm{CPK}$ level after the combat training course $(p<0.001)$. The mean value of CPK was $843.51 \mathrm{U} / \mathrm{L}$ \pm 0.316 (SES) with a range of 126 to $2148 \mathrm{U} / \mathrm{L}$. In $8.8 \%$ of participants, the creatine phosphokinase level remained in the reference range. In $21 \%$ of participants, the CPK level increased 3 times the baseline level, in $50.9 \%$ of participants the CPK level increase was four times the baseline level, and in $3.5 \%$ of participants the level of CPK exceeded five times the baseline level. The observed increase indicates damage to creatine kinase rich tissue during combat training course.

Lactate dehydrogenase (LDH, reference range 122-222 $\mathrm{U} / \mathrm{L}$ ) is an enzyme found in many cells of the body tissue. $\mathrm{LDH}$ is responsible for conversion of muscle lactate to pyruvate, which is a significant step in energy production of cells. LDH also indicates damage to muscle tissue after high physical load. The mean LDH values before the combat training course was $197.76 \mathrm{U} / \mathrm{L} \pm 0.311$ (SES). Initial LDH levels exceeded reference range in $18.6 \%$ of participants. The McNemar statistical test showed a significantly raised level of Lactate dehydrogenase increase after the combat training course $(p<0.001)$. The level of LDH in more than $91.5 \%$ of participants increased after the combat training course, but in $5.1 \%$ of participants it remained within the reference range. In $57.9 \%$ of participants the LDH level increased two times. The mean value of Lactate dehydrogenase after combat training course was $356.04 \mathrm{U} / \mathrm{L} \pm 0.316$ (SES), varying from 203 to $529 \mathrm{U} / \mathrm{L}$.

The level of aspartate amino transferase (AST, reference range 5-34 U/L) increases in cases of damage to tissues and cells including muscles, heart, red blood cells, and liver. In our study, the mean AST level before the combat training course was $23.85 \mathrm{U} / \mathrm{L} \pm 0.311$ (SES) with a range of 14 to $49 \mathrm{U} / \mathrm{L}$. The level of AST was in the reference range for all participants. The AST level increased in $80.7 \%$ of participants after the combat training course. The mean value of AST was $53.44 \mathrm{U} / \mathrm{L} \pm 0.316(\mathrm{SES})$ with a range of 21 to $104 \mathrm{U} / \mathrm{L}$. The elevated enzyme levels indicated damage to muscles.

Alanine amino transferase (ALT, reference range 0-55 U/L) is one of the most sensitive markers of liver damage. ALT levels were in the reference range in $98.3 \%$ of participants before the combat training course. An elevated level of ALT was found in $1.7 \%$. The mean value of ALT was 28.07 $\mathrm{U} / \mathrm{L} \pm 0.311$ (SES), range from 16 to $98 \mathrm{U} / \mathrm{L}$. An increased ALT level was found in $25.9 \%$ of participants after high 
PLASMA LEVELS OF ENZYMES BEFORE (LACTATE DEHYDROGENASE (LDH1), CREATINE PHOSPHOKINASE (CPK1), ALANINE AMINO TRANSFERASE (ALT1) AND ASPARTATE AMINO TRANSFERASE (AST1) AND AFTER (LACTATE DEHYDROGENASE (LDH2), CREATINE PHOSPHOKINASE (CPK2), ALANINE AMINO TRANSFERASE (ALT2) AND ASPARTATE AMINO TRANSFERASE (AST2) THE COMBAT TRAINING COURSE

\begin{tabular}{|c|c|c|c|c|c|c|c|c|}
\hline & ALT1 & ALT2 & AST1 & AST2 & LDH1 & LDH2 & CPK1 & CPK2 \\
\hline Mean & 28.07 & 47.16 & 23.85 & 53.44 & 197.76 & 356.04 & 235.97 & 843.51 \\
\hline SEM & 1.514 & 1.951 & .875 & 2.684 & 3.341 & 9.697 & 21.538 & 65.457 \\
\hline Median & 26.00 & 49.00 & 24.00 & 52.00 & 193.00 & 351.00 & 189.00 & 663.00 \\
\hline SD & 11.629 & 14.732 & 6.718 & 20.263 & 25.662 & 73.208 & 165.438 & 494.191 \\
\hline Skewness & 3.934 & 0.376 & 1.485 & 0.538 & 0.364 & 0.111 & 1.751 & 0.633 \\
\hline Std. Error of Skewness & 0.311 & 0.316 & 0.311 & 0.316 & 0.311 & 0.316 & 0.311 & 0.316 \\
\hline Minimum & 16 & 16 & 14 & 21 & 152 & 203 & 57 & 126 \\
\hline Maximum & 98 & 93 & 49 & 104 & 257 & 529 & 824 & 2148 \\
\hline Percentiles 25 & 21.00 & 35.00 & 19.00 & 36.50 & 179.00 & 300.00 & 124.00 & 463.50 \\
\hline Percentiles 50 & 26.00 & 49.00 & 24.00 & 52.00 & 193.00 & 351.00 & 189.00 & 663.00 \\
\hline Percentiles 75 & 32.00 & 56.00 & 26.00 & 65.50 & 213.00 & 409.00 & 279.00 & 1183.00 \\
\hline
\end{tabular}

physical load in the combat training course. The mean ALT level in the examined group was $47.16 \mathrm{U} / \mathrm{L} \pm 0.316$ (SES) with a range of 16 to $93 \mathrm{U} / \mathrm{L}$. In $56.1 \%$ of participants the level of ALT increased 2 times the baseline level, in $7 \%$ the increase was three times the baseline level, but in $1.7 \%$ ALT increased between 4-5 times the baseline level.

Table 3 shows that the levels of biochemical markers lactate dehydrogenase (LDH), creatine phosphokinase (CPK), alanine amino transferase (ALT) and aspartate amino transferase (AST) increased in participants during a combat training course due to high physical load. Elevation of biochemical markers indicated cardiovascular and musculoskeletal risk associated with physical load. The intense physical training may account not only for the increased level of biochemical markers but also for substantial changes of body composition observed.

Blood glucose (GLU, reference range 3.89-5.83 $\mathrm{mmol} / \mathrm{L}$ ) levels are tightly regulated by a variety of stimuli and mechanisms. It is important for metabolic homeostasis. The mean plasma glucose level remained in the reference range both before and after combat training course: $4.74 \mathrm{mmol} / \mathrm{L}$ $\pm 0.31(\mathrm{SES})$ and $4.79 \mathrm{mmol} / \mathrm{L} \pm 0.316(\mathrm{SES})$, respectively.

Plasma sodium concentration ( $\mathrm{Na}$, reference range 135-150 $\mathrm{mmol} / \mathrm{L}$ ) characterises fluid balance and hydration level. The mean plasma sodium concentration before and after the combat training course was $140.66 \mathrm{mmol} / \mathrm{L} \pm 0.311$ (SES), and was $139.51 \mathrm{mmol} / \mathrm{L} \pm 0.316(\mathrm{SES})$, respectively. The levels indicated an adequate hydration level during the high load training course.

The plasma potassium level $(\mathrm{K}$, reference range 3.5-5.0 $\mathrm{mmol} / \mathrm{L}$ ) affects contractile function of striated and smooth muscle, e.g. skeletal muscle, muscles of the digestive tract and muscle of the heart. The plasma potassium level was within the reference range both before and after the combat training course. The mean potassium level before combat training course was $4.52 \pm 0.311(\mathrm{SES}) \mathrm{mmol} / \mathrm{L}$ and $4.61 \pm$ 0.316 (SES) $\mathrm{mmol} / \mathrm{L}$ after the combat training course. No significant differences were shown in plasma potassium levels in combat training course participants.

Deviation in the plasma magnesium level $(\mathrm{Mg}$, reference range $0.7-1.0 \mathrm{mmol} / \mathrm{L}$ ) can cause interference with neuromuscular activity. It is an important cofactor for various enzymes, transporters, and nucleic acids that are essential for normal cellular function, replication, and energy metabolism. Plasma magnesium levels remained in the reference range both before and after combat training course in all participants, with mean values $0.79 \mathrm{mmol} / \mathrm{L} \pm 0.311$ (SES) and $0.85 \mathrm{mmol} / \mathrm{L} \pm 0.316(\mathrm{SES})$, respectively.

Table 4 shows that the levels of biochemical markers glucose (GLU), sodium concentration $(\mathrm{Na})$, potassium level $(\mathrm{K})$, and magnesium level $(\mathrm{Mg})$ remained stable during the combat training course in participants during high physical load.

\section{DISCUSSION}

Young persons were exposed to a relatively brief, but extremely intense and structured period of physical and mental training. The combat training course module included a combination of various military surrounding risk factors (physical exercise, psychological load, dietary limitation, sleep deprivation). The first finding of our study concerned anthropometric characteristics of participants before and after combat training course. We observed that $42.5 \%$ of male participants had a BMI in the WHO reference range while $48.9 \%$ of participants had a BMI that exceeded the range by up to $10 \%(25.0-27.9)$ and $8.5 \%$ of participants were classified as overweight and exceeded the range by up to $20 \%$ (28.8-30.0). In $75 \%$ of female participants the BMI was in the normal range, but the remaining females had a BMI up to $10 \%$ above the normal range (25.0-27.9). Substantial 
GLUCOSE AND ELECTROLYTES LEVELS BEFORE (GLUCOSE (GLU1), SODIUM CONCENTRATION (NA1), POTASSIUM LEVEL (K1), AND MAGNESIUM LEVEL (MG1) AND AFTER (GLUCOSE (GLU2), SODIUM CONCENTRATION (NA2), POTASSIUM LEVEL (K2), AND MAGNESIUM LEVEL (MG2) THE COMBAT TRAINING COURSE

\begin{tabular}{lcc|c|c|c|cc|cc}
\hline & GLU1 & GLU2 & Na1 & Na2 & K1 & K2 & Mg1 & Mg2 \\
\hline Mean & 4.7415 & 4.7905 & 140.66 & 139.51 & 4.515 & 4.612 & 0.7908 & 0.8518 \\
SEM & 0.08170 & 0.07496 & 0.185 & 0.264 & 0.0330 & 0.0417 & 0.00658 & 0.00566 \\
Median & 4.7800 & 4.8300 & 141.00 & 140.00 & 4.500 & 4.600 & 0.7800 & 0.8600 \\
SD & 0.62754 & 0.56591 & 1.422 & 1.992 & 0.2531 & 0.3146 & 0.05056 & 0.04273 \\
Skewness & -0.636 & -0.329 & -0.115 & -1.853 & 0.839 & 0.275 & 0.128 & -0.125 \\
Std. Error of Skewness & 0.311 & 0.316 & 0.311 & 0.316 & 0.311 & 0.316 & 0.311 & 0.316 \\
Minimum & 2.55 & 3.52 & 137 & 130 & 4.0 & 3.7 & 0.69 & 0.74 \\
Maximum & 6.21 & 6.38 & 144 & 143 & 5.3 & 5.6 & 0.91 & 0.96 \\
Percentiles 25 & 4.4200 & 4.4250 & 140.00 & 138.00 & 4.300 & 4.400 & 0.7500 & 0.8200 \\
Percentiles 50 & 4.7800 & 4.8300 & 141.00 & 140.00 & 4.500 & 4.600 & 0.7800 & 0.8600 \\
Percentiles75 & 5.1200 & 5.0550 & 142.00 & 141.00 & 4.600 & 4.800 & 0.8300 & 0.8800
\end{tabular}

changes occur in body composition during intense physical and stressful psycho-emotionally training in combination with dietary limitation and sleep deprivation. This study demonstrated deviations of body mass and BMI value during and after CTC. The combat training course is a systematic process that combines competitive athletic training with high intensive physical load and psychological stress. A decrease in body mass was found during the combat training course (CTC). During the first day of CTC $70.6 \%$ of cadets lost $1-2 \mathrm{~kg}$ body weight, but for $8.5 \%$ of individuals the decrease of body weight was by up to $3-4 \mathrm{~kg}$; for $21.8 \%$ of cadets the body weight values were stable. We found that the maximal loss of body weight appeared on the fifth day of CTC, when the peak of physical and emotional stress was reached. Analysis of BMI variation during combat training course showed decrease of the mean BMI in both genders.

The second finding of our study concerned biochemical parameters of participants before and after the combat training course. We observed substantial changes in several biochemical markers (lactate dehydrogenase (LDH) and creatine phosphokinase (CPK) related to musculoskeletal disorders for participants of both genders during the short intensive training course. During CTC, cadets had vigorous physical activities that resulted in abrupt increase of creatine phosphokinase (CPK) levels over the reference range in $98.2 \%$ of participants.

In $8.8 \%$ of participants CPK levels remained in the reference range. In $21 \%$ of participants $\mathrm{CPK}$ levels increased three times the baseline amount. In $50.9 \%$ of participants CPK levels increase was four times the baseline amount and in $3.5 \%$ of participants the level of CPK exceeded the baseline level five times. The level of lactate dehydrogenase in more than $91.5 \%$ of participants increased after the combat training course (CTC), but in $5.1 \%$ of participants it remained within the reference range. The level of lactate dehydrogenase increased two times the baseline amount in $57.9 \%$ of participants. The differences in levels of biochemical markers between the start position (before CTC) and end position (after CTC) are related to physical fitness and physical load level. The findings of our study demonstrated high risk of musculoskeletal disorders in participants of CTC.

The intense physical training did not affect other biochemical markers like glucose (GLU), sodium concentration $(\mathrm{Na})$, potassium level $(\mathrm{K})$, and magnesium level $(\mathrm{Mg})$. Reduction of food consumption and sleep deprivation is consistent with reduction of working capacity. High physical activity level and intense physical load were factors that could be responsible for changes in body composition and biochemical parameters.

Military personnel are subjected to high physical load, therefore identification and prevention of musculoskeletal disorders at an early stage may allow to reduce risk of development of chronic disease. The nature of these disorders suggests that interplay of various contributing circumstances, like psychosocial, ergonomic, individual/organizational, intrinsic and extrinsic factors associated with the military environment will cause musculoskeletal dysfunction.

In recent years a growing number of studies have examined changes in levels of biochemical markers due to physical load. Most of them have focused on athletes, but there are some studies on military personnel in relation to their physical fitness and combat readiness.

\section{CONCLUSION}

In $42.5 \%$ of male participants BMI remained in normal range (18.0-24.9). 10\% increase of BMI ( 25-27.9) was found in $48.9 \%$ of male participants and a $20 \%$ increase of BMI (28.0-29.9, referred as overweight) occurred in $8.5 \%$ of male participants. In $75 \%$ of female participants BMI was in normal range, but the other females had a BMI up to $10 \%$ above the normal range. 
Changes of mean values of the body mass during ten-day long combat training course were found in all participants. The body mass values decreased until the fifth day of combat training course resulting in loss of $4-5 \mathrm{~kg}$ in $56.8 \%$ and loss of $6-7 \mathrm{~kg}$ in $22.4 \%$ of participants. The mean BMI values decreased for both genders during combat training course. A slight difference in the rate of BMI decrease was found between genders. In the female group decrease of BMI values was more intense compared to the male group.

Plasma biochemical markers like glucose (GLU), sodium concentration $(\mathrm{Na})$, potassium level $(\mathrm{K})$, and magnesium level $(\mathrm{Mg})$ were stable during the combat training course (CTC) in participants subjected to high physical load. During the course cadets underwent vigorous physical activities that resulted in abrupt increase of creatine phosphokinase levels over the reference range in $98.2 \%$ of participants. The $\mathrm{McNemar}$ statistical test revealed a significantly raised creatine phosphokinase level after CTC $(p<0.001)$. LDH also can be used to indicate damage to muscle tissue after high physical load. The McNemar statistical test revealed a significantly raised level of lactate dehydrogenase after combat training course $(p<0.001)$.

\section{REFERENCES}

Aandstad, A., Holtberget, K., Hageberg, R., Holme, I., Anderssen, S. A. (2014). Validity and skinfold thickness in predicting body fat in military personnel. Military Med., 179 (2), 208-217.

Anonymous (2012). World Health Statistics 2012. World Health Organization. Available from: http://www.who.int/gho/net (accessed 13.05.2019).

Baar, K. (2015). Training and nutrition to prevent soft tissue injuries and accelerate return to play. Sports Sci. Exchange, 28 (142), 1-6.

Barringer, N. D., Pasiakos, S. M., McClung, H. L., Crombie, A. P., Margolis, L. M. (2018). Association between stress fracture incidence and predicted body fat in United States Army Basic Combat Training recruits. J. Int. Soc. Sports Nutr., 15 (15), 1-9.

Clark, H. L., Heileson, J., Demay, J., Cole, R. E. (2017). Misperceptions of weight status in military men and women. Military Med., 182 (5), e1792-e1798.

da Rosa, S. E., Martinez, E. C., Marson, R. A., Fortes, M. S. R., Filho, J. F. (2018). Military physical training, muscular strength, and body composition of Brazilian military personnel. Revista Brasileira de Medicina do Esporte, 24 (2), 153-156.

Fallowfield, J. L., Delves, S. K., Hill, N. E., Cobley, R. C., Brown, P., Lanham-New, S. A., Frost, G., Brett, J. S., Murphy, K. G., Montain, S. J., Nicholson, C., Stacey M., Ardley, C., Shaw, A., Bentley, C., Wilson, D. R., Allsopp, A. J. (2014). Energy expenditure, nutritional status, body composition and physiscal fitness of Royal Marines during 6-month operational deployment in Afghanistan. Brit. J. Nutr., 112, 821-829.

Halson, S. L. (2014). Monitoring fatigue and recovery. Sports Sci. Exchange, 27 (135), 1-6.
Havenetidis, K., Paxinos, T., Kardaris, D., Bissas, A. (2017). Prognostic potential of body composition indices in detecting risk of musculoskeletal injury in army officer cadet profiles. Phys. Sports Med., 45 (2), 114-119.

Jones, A. M. (2016). Dietary nitric oxide precursors and exercise performance. Sports Sci. Exchange, 28 (156), 1-6.

Jones, B. H., Hauret, K. G., Dye, S. K., Richardson, M. D., Friedl, K. E. (2017). Impact of physical fitness and body composition on injury risk among active young adults: A study of Army trainees. J. Sci. Med. Sport, 20, S17-S22.

Karlsson, J, Nordesjo, L. O, Jorfeldt, L., Saltin, B. (1972). Muscle lactate, ATP, and CP levels during exercise after physical training in man. J. Appl. Physiol., 33 (2), 199-203.

Liberman, H. R., Kellogg, M. D., Batholon, G. P. (2008). Female marine recruit training: Mood, body composition, and biochemical changes. Med. Sci. Sport Excerc., 671-676.

McCarthy, M. S., Elshaw, E. B., Szekely, B. M., Pflugeisen, B. (2017). Health promotion research in active duty army soldiers: The road to a fit and ready force. Nursing Outlook, 65 (5), S6-S16.

Mitchell, K. M., Pritchett, R. C., Gee, D. L., Pritchett, K. L. (2017). Comparison of circumference measures and height-weight tables with dual-energy X-ray absorptiometry assessment of body composition in R.O.T.C. cadets. J. Strength Condit. Res., 31 (9), 2552-2556.

Naghii, M. R. (2006). The importance of body weight and weight management for military personnel. Milit. Med., 171 (6), 550-555.

Nozaki, S., Tanaks, M., Mizuno K., Ataka, S., Mizuma, H., Tahara T., Sugino, T., Shirai, T., Eguchi, A., Okuyama, K., Yoshida, K., Kajimoto, Y. Y., Kuratsune, H., Kajimoto, O., Watanabe, Y. (2009). Mental and physical fatigue-related biochemical alterations. Nutrition, 25 (1), 51-57.

Parkkari, J., Taanila, H.,Suni J., Mattila, V. M., Ohrankämmen, O., Vuorinen, P., Kannus, P., Pihlajamäki, H. (2011). Neuromuscular training with injury prevention counselling to decrease the risk of acute musculo skeletal injury in young men during military service: A population-based, randomised study. BMC Medicine, 9, 35 (1-12).

Sammito, S., Gundlach, N., Bockelmann, I. (2016). Correlation between the results of three physical fitness tests (endurance, strength, speed) and the output measured during a bicycle ergometer test $\mathrm{n}$ a cohort of military servicemen. Milit. Med. Res., 3 (12), 1-6.

Sanderson, P. W., Clemes, S. A., Friedl, K. E., Biddle, S. J. H. (2018). The association between obesity related health risk and fitness test results in the British Army personnel. J. Sci. Med. Sport, 21 (11), 1173-1177.

Taanila, H., Suni, H. J., Kannus, P., Pihlajamäki, H., Ruohola, J. P., Viskari, J., Parkkari, J. (2015). Risk factors of acute and overuse musculoskeletal injuries among young conscripts: A population-based cohort study. BMC Musculoskel. Disord., 16 (104), 1-19.

Tassone, E. C., Baker, B. A. (2017). Body weight and body composition changes during military training and deployment involving the use of combat rations: A systematic literature review. Brit. J. Nutr., 117 (6), 897-910.

Thorstensson, A., Hultén, B., von Döbeln, W., Karlsson J. (1976). Effect of strength training on enzyme activities and fibre characteristics in human skeletal muscle, 96 (3), 392-398.

Wallimann, Th., Tokarska, M., Schlattner, U. (2011). The creatine kinase system and pleiotropic effects of creatine. Amino Acids, 40 (5), 1271-1296.

Etzion-Daniel, Y., Constantini, N., Finestone, A. S., Shahar, D. R., Israeli, E., Yanovich, R., Moran, D. S. (2008). Nutrition consumption of female combat recruits in army basic training. Med. Sci. Sports Exerc., 40 (11 Suppl.), 677-684. 


\section{ANTROPOMETRISKO PARAMETRU UN BIOKĪMISKO RĀDĪTĀJU IZMAIN̦AS MILITĀRPERSONĀM AUGSTAS FIZISKAS UN PSIHOLOG̦ISKAS SLODZES IETEKMĒ}

Fiziskā sagatavotība, veselība un fiziskā un psiholoğiskā izturība ir nozīmīgi komponenti militārpersonas veiksmīgai dienesta gaitai. Topošo virsnieku sagatavošanas posmā karavīra izturības kursā kadetiem tiek trenētas gan fiziskās, gan psiholoğiskās izturības īpašības militārai videi tuvinātos apstākḷos. Pētījuma gaitā pirms un pēc kursa tika izvērtēts visu tā dalībnieku fiziskās veselības stāvolis, antropometriskie rādītāji, biokīimiskie rādītāji (laktātdehidrogenāze (LDH), kreatīnfosfokināze (KFK), Alanīnaminotransferāze (ALAT) un aspartātaminotransferāze (ASAT), kas definē iespējamo muskuḷaudu bojājumu augstas fiziskas slodzes ietekmē, kā arī noteikts glikozes un elektrolītu līmenis asins plazmā. Kursa laikā tika veikts svara monitorings, un lielākie svara zaudējumi, 3-4 kg, pusei dalībnieku tika fiksēti uz kursa sesto dienu — karavīra izturības kursa kulminācijas smagāko posmu. Kermena masas indeksa (KMI) izmainas slodzes ietekmē un ierobežota uztura un miega režīma iespaidā izteiktākas bija sievietēm salīdzinājumā ar vīriešiem. Gandrīz visiem kursa dalībniekiem strauji, statistiski ticami pieauga LDH un KFK līmenis asins plazmā, kas liecina par muskuḷaudu bojājumiem, bet glikozes līmenis, kā arī kālija un magnija līmenis asins plazmā bija stabils, atbilstošs standarta lielumiem. Iegūtie dati ir aktuāli un militārpersonu (kadetu) sagatavošanas aspektā ḷauj izvērtēt fiziskās slodzes individuālo atbilstību, veikt tās pamatotu plānošanu studiju programmā. Pētījuma dati parāda nepieciešamību sekmīgāk un agrīnāk uzsākt kursa sagatavošanas posmu, veikt kompleksu veselības kapacitātes izvērtējumu, iekḷaujot specifisku enzimātisko bioḳīmijas daḷu, lai veiksmīgi trenētu militārpersonu psiholoğisko un fizisko izturību un saglabātu fizisko veselību. 